\title{
原著
}

\section{恙虫病リケッチアの抗原性に関する研究 *}

\author{
桑田次男 ${ }^{* *}$
}

[受稿：4月15日, 1953]

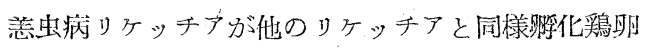
々黄囊内て增殖可能で多ることは秋田及澎湖島の株を

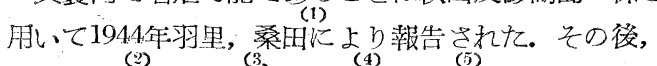
Bengtson, Topping,'Clancy, Smadel 年等に上り東献 ジアの諸地域に於て分離されて株の鶏耶内境着か蕔告

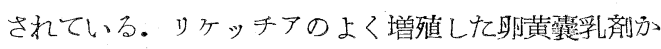
らは土ーテル抽出法により補体結合反応抗原が作られ それ学機緑として南方各地に於て分離されたり穴ッチ

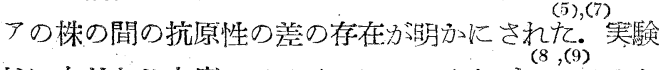
的炕有效な恙虫病のワクチンはハッカネズミ, ワタネ ズミ,ダイコタネボミ等の諸藏器, 或はZ Zinsser 法に

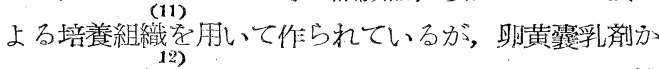
はらBailey等の分劃遠心法によりリケッチア定精製跸 縮する方法以外には未年成功していない。

私は日本の恙虫病流行地上り分離されたりケッチア

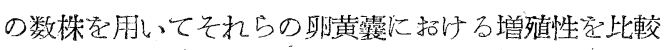

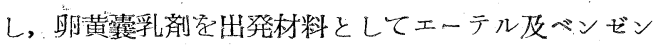
が補体結合反応の抗原性並びにハッカネズミに対する

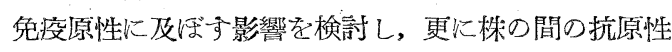
の䇪つ存在空も調ベて見た。

\section{実験材料之実験方法}

リケッチア株：1948年夏新潟の信濃川沿岸に於て発 生して患者の血液上り分離してS. 3, S. 4, S. 6, S.7, S. 11, S, 13の 6 株及び阿賀川流域の患者上り分離され た AX, Gの2 株が使用された。等の株はハッカネ ズミの腹腔内接種法に上り分離され，ハッカネズミで 継代された。

感染䛧の測定：生理的食塩水で10倍に稀釈した脱脂

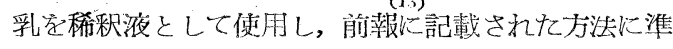

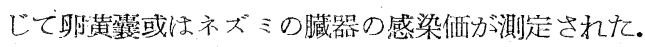

笑験動物：10 12 gr. 前後の雑種ハツカネズミ及び 80 100gr.のダイコクネズミが傎用された.

補体結合反応: 発疹于フ大, 発疹熱の息清学的猃断 の際施行されているオ法と略々同一の術式を採用し た. 即ち倍数稀秋した年清 $0,25 \mathrm{~m} 1$ 亿等量の 4 単位の抗 原及び 2 充単位の補体 $0.5 \mathrm{~m} 1$ 定加兄一夜水空に收的 に 3 パーセント緬羊血球安 3 単位の溶血素で感作した 血球 $0.5 \mathrm{ml}$ 学加兄て $37^{\circ} \mathrm{C}$ の温浴に 30 分間放置し結果 定判定した。抗原価の測定には 8 単位の抗体定ふくも テンジクネズミ血清が使用されて。

抗原及びワクチンの製法恃夫々些験の項に於て記載 される。

\section{実 験 成 績}

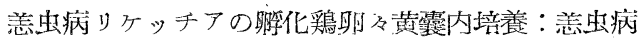
リケッチアの感染眀黄垔乳剂より補体結合反応抗原及 びワクチン定作るために, 先ず数榴のリケッチアの䏅

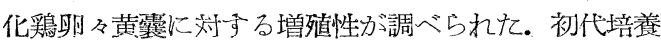

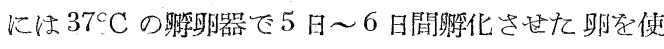
用する・リケッチアに感染, 発症して頻死のハッカネ ボミを解剖しとの肝臓のほ心゙10倍孚剂 $0.3 \mathrm{~m} 1$ 它形の如

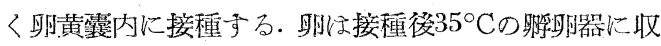
めて 8 日〜10日間培養し，次に之等の卵の卵黄囊を集 めて乳鄅とし初代と同様5 日〜 6日の㥸接種する。 2 代以後ではリケッチア接種後 6 日乃至 8 日で畞は死 亡し始めるので生き残つた明の久学次代つ接種材料と

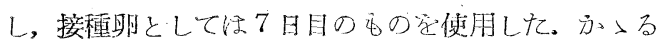
方法に上り上記 8 株のリケッチアの䀦黄垔に対する增 殖性を比較して所, AX 株は培養 2 代に於て少数のり

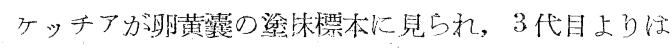

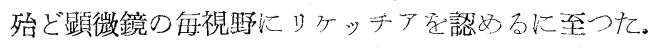

* 本研究の一部は文部省科学研究費の䋠助をらけて行はれた。

**葉大学医学部細菌学教空 
かくしてAX株は町黄囊を16代継代されてが各代共り ケッチアの検出が染色上可能であつた. 所が他の 7 株 にめつては 6 代乃至 10 代畉黄藏内琣養を継続しその感 染洒は S. 13株を除きいづれるLD50 10-7 前後であつ てが，淮抹標本に於てりケッチアを証明することが出 来なかつて S. 13株は畉黄整内で 6 代継代したがLD50

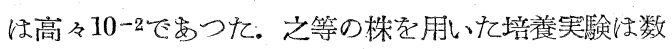
回繰りかえされたが常に同一の成績に終つた。. 恙虫病

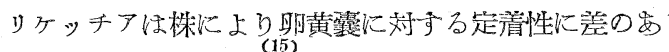
ることは Lewthwaite等も報告しているが，それはこ のリゥッチアの特徴をなするので焉らう。発疹チフス 或は発疹熱リァッチアに於ては株によるその様な差異 は報告されていない。

補体結合反応抗原の作製：上記 AX株が矂黄霆内で よく増殖することを認めたのでその 3 代目の瞓黄囊よ り補体結合反応の抗原作製安試みて。即ちリケッチア

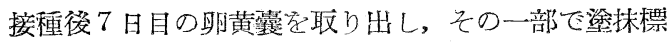

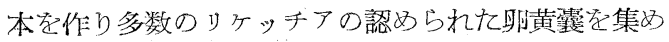
pH7.2 の燐酸緩衝液空加えて乳銪で20パーセントの乳 抄とし，直ちに傾角遠心器でドライアイスで冷却しつ
$>$ 10,000r.p.m. 20分間遠心した. 沈湟管の上層に浮ぶ クリーム状の瑰りを先づ取り去り次に上清液定注射器 で取りすてる，沈渣には原量と等量の政酸緩衝液を加 えてよく混和し之分液濾斗火入れ，等量の冷却した エーテルを加えて数回振温して後水室に収め水層と土 ーテル層とが分離したならばなるへくく早く水層部のみ 走分離する (通常10分乃至20分)。之夜水室に保存 し生じた少量の沈激を軽く遠心して除き抗原として使 用した. 免度血清としては感染ハッカネズミの肝乳偊 の腹腔内に注射により生き残つたテンジクネズミの血 清定解熱後 3 週間目に採血して使用した。 補体結合反 応の結果は第 1 表に示されている。この抗原により 7 例の恙虫病患者血清について補体結合反応を行つた（ 第 2 表).

Wolff等は畉黄簬の50パーセント乳刜を凍結乾燥し ベンゼン,アセトンその他の有機溶媒で復抽出し補 体結合反忘抗原老作つている。私は日本脳炎抗原作製 の場命の Espana 等の方法に準じたベンゼン抽出法に より抗原学作り好結果学得扟。即ち AX株第 6 代眀黄 覆の 20 パーセント乳䠼家2,000r.p.m. 10 分遠心しその

Tabl 1. Titration of Ether-and Benzene-extracted Antigens for Tsutsugamushi Disease

\begin{tabular}{|c|c|c|c|c|c|c|c|c|c|c|}
\hline \multirow{2}{*}{$\begin{array}{l}\text { Antigen } \\
\begin{array}{c}\text { Antigen } \\
\text { dilution }\end{array} \\
\text { Serum } \\
\text { dilution }\end{array}$} & \multicolumn{5}{|c|}{ Ether-extracted Antigen } & \multicolumn{5}{|c|}{ Benzene-extracted Antigen } \\
\hline & $1 / 4$ & $1 / 8$ & $1 / 16$ & $1 / 32$ & $1 / 64$ & $1 / 8$ & $1 / 16$ & $1 / 32$ & $1 / 64$ & $1 / 128$ \\
\hline $1: 10$ & 4 & 4 & 4 & 4 & 1 & 4 & 4 & 4 & 3 & 0 \\
\hline $1: 20$ & 4 & 4 & 3 & \pm & 0 & 4 & 4 & 4 & 3 & 0 \\
\hline $1: 40$ & 4 & 4 & 1 & 0 & 0 & 4 & 4 & 4 & \pm & 0 \\
\hline $1: 80$ & 4 & 3 & 0 & 0 & 0 & 4 & 3 & 3 & 0 & 0 \\
\hline $1: 160$ & 1 & \pm & 0 & 0 & 0 & \pm & 0 & 0 & 0 & 0 \\
\hline $1: 320$ & \pm & 0 & 0 & 0 & 0 & 0 & 0 & 0 & 0 & 0 \\
\hline Antigen control & 0 & 0 & & & & 0 & & & & \\
\hline
\end{tabular}

Table 2. Complement-fixation Test on Sera of Patients Collected at Niigata. Antigen: Ether-extracted $1: 4$

\begin{tabular}{|c|c|c|c|c|c|c|c|c|c|c|c|c|}
\hline \multirow{2}{*}{$\begin{array}{l}\text { Case } \\
\text { No. }\end{array}$} & \multirow{2}{*}{$\begin{array}{c}\text { Date of } \\
\text { Onset }\end{array}$} & \multirow{2}{*}{$\begin{array}{l}\text { Date of } \\
\text { Serum } \\
\text { Drawn }\end{array}$} & \multicolumn{8}{|c|}{ Dilution of Serum } & \multicolumn{2}{|c|}{$\begin{array}{l}\text { Serum } \\
\text { Contro1 }\end{array}$} \\
\hline & & & $1 / 4$ & $1 / 8$ & $1 / 16$ & $1 / 32$ & $1 / 64$ & $1 / 128$ & $1 / 256$ & $1 / 512$ & $1 / 4$ & $1 / 8$ \\
\hline 1. & Ju1. 17 & Nou. 7 & 4 & 4 & 4 & 4 & 1 & \pm & 0 & 0 & 0 & 0 \\
\hline 2. & Ju1. $\quad 24$ & Nou. 7 & 2 & 1 & \pm & 0 & 0 & 0 & 0 & 0 & 0 & 0 \\
\hline 3. & Aug. 7 & Nou. 7 & 4 & 4 & 2 & \pm & 0 & 0 & 0 & 0 & 0 & 0 \\
\hline 4. & Aug. 9 & Nou. 7 & 4 & 3 & 1 & 0 & 0 & 0 & 0 & 0 & 0 & 0 \\
\hline 5. & Aug. 10 & Nou. 7 & 1 & 0 & 0 & 0 & 0 & 0 & 0 & 0 & 0 & 0 \\
\hline 6. & Aug, 19 & Nou. 7 & 4 & 4 & 4 & 4 & 4 & 4 & 3 & 2 & 0 & 0 \\
\hline
\end{tabular}


Table 3. Complement-fixation Test on Sera of Guinea Pigs 1mmunized with Strains of Tsutsugamushi Disease Rickettsia. Antigen: Benzene extracted. $1: 8$

\begin{tabular}{|c|c|c|c|c|c|c|c|c|c|c|}
\hline \multirow{2}{*}{$\begin{array}{l}\text { Strains Used } \\
\text { for } \\
\text { Immunization }\end{array}$} & \multirow{2}{*}{$\begin{array}{c}\text { Immune } \\
\text { Sera }\end{array}$} & \multicolumn{7}{|c|}{ Dilution of Serum } & \multicolumn{2}{|c|}{ Serum Control } \\
\hline & & $1 / 4$ & $1 / 8$ & $1 / 16$ & $1 / 32$ & $1 / 64$ & $1 / 228$ & $1 / 256$ & $1 / 4$ & $1 / 8$ \\
\hline \multirow{2}{*}{ S. 3} & 1. G. P. & 4 & 0 & 0 & 0 & 0 & 0 & 0 & 0 & 0 \\
\hline & 2. G. P. & 4 & 3 & \pm & 0 & 0 & 0 & 0 & 0 & 0 \\
\hline \multirow{2}{*}{ S. 7} & 1. G. P. & 0 & 0 & 0 & 0 & 0 & 0 & 0 & 0 & 0 \\
\hline & 2. G. P. & 4 & 4 & \pm & 0 & 0 & 0 & 0 & 0 & 0 \\
\hline \multirow{2}{*}{ S. 11} & 1. G. P. & 4 & 4 & 4 & 3 & \pm & 0 & 0 & 0 & 0 \\
\hline & 2. G. P. & 4 & 4 & 4 & 4 & 4 & 0 & 0 & 0 & 0 \\
\hline \multirow{2}{*}{ S. 13} & 1. G. P. & 0 & 0 & 0 & 0 & 0 & 0 & 0 & 0 & 0 \\
\hline & 2. Mice & 0 & 0 & 0 & 0 & 0 & 0 & 0 & 0 & 0 \\
\hline \multirow{3}{*}{$\mathrm{AX}$} & 1. G. P. & 4 & 4 & 4 & 4 & 4 & 1 & 0 & 0 & 0 \\
\hline & 2. G. P. & 4 & 4 & 4 & 4 & \pm & 0 & 0 & 0 & 0 \\
\hline & 3. Rabbit & 4. & 4 & 4 & \pm & 0 & 0 & 0 & 1 & 0 \\
\hline
\end{tabular}

Table 4. Soluble Antigen of Tsutsugamushi Disease Rickettsia Prepared from Yolk Sac by Ether-and Benzene-extraction Procedures.

\begin{tabular}{|c|c|c|c|c|c|c|c|c|c|c|}
\hline \multirow{2}{*}{$\frac{\text { Antigen }}{\text { Antigen dilution }}$} & \multicolumn{5}{|c|}{ Ether-extracted Antigen } & \multicolumn{5}{|c|}{ Benzene-extracted Antigen } \\
\hline & $1 / 4$ & $1 / 8$ & $1 / 16$ & $1 / 32$ & $1 / 64$ & $1 / 4$ & $1 / 8$ & $1 / 16$ & $1 / 32$ & $1 / 64$ \\
\hline Before centrifugation & 4 & 4 & 4 & 1 & 0 & 4 & 4 & 4 & 3 & 0 \\
\hline $\begin{array}{l}\text { Supernatant } \\
(10,000 \mathrm{r} . \mathrm{p} . \mathrm{m} .20 \mathrm{~min} .)\end{array}$ & 4 & 4 & 2 & 0 & 0 & 4 & 4 & 4 & 3 & 0 \\
\hline Sediment & \pm & 0 & 0 & 0 & 0 & 0 & 0 & 0 & 0 & 0 \\
\hline
\end{tabular}

上清を凍結乾燥し，ガラスフィルターを使用して兴温。 で倍量のベンゼン学加光抽出を30分づう2 回行つた後 真空ポンプでベンゼン焉吸引し，乾燥粉末集め原量 の翗酸緩㣫液に溶解して抗原を作つた。 その抗原性は 第1表に示されている。

このベンゼン抽出抗原の 4 単位堂使用して, S.3, S.

7, S. 11, S. 13, AX の各株に対す万免疫血清の抗体価 が測定された。第3表に示された様に略々同様の処置 で作られた色疫血清の抗体洒化著明な差が認められ て、免疫亚清学作る際S.13株の接㮔をつけたテンジク ネズミは発熱定示すことがなかつたし，感染の軽重が 各動物の抗体価の高低に影響していることも考えられ るが，各株の間に抗原性の差があり抗体価に美の生じ たことも考慮されよ5。抗原はAX株 1 株加らの久作 られているため之等の憡の間の抗原性の善については 決定的なことはこ〉に述べられない。
抗原の性状：Smadel 等は湵虫病りケッチアの濃厚 乳剂の静脈内接種空 万けて感染後 4万至5 日で死しし たハッカネボミの面清, 肋膜院洷出液, 或は肺, 脾乳 剂より至温で 4 乃至 6 時閒エーテル抽出定行い作つた 抗原が18,400 r.p.m. 1 時聞半の遠心により力洒の減弱 が見られず，他方泿渣に抗原性の見られない点よりそ れ务部謂可溶性抗原に属すること学証明している。私 は上記の方法によつて作製して抗原が同様可溶性抗原 に属するか否方学調べて見た。第 4 表に見られる通り 町黄囊乳都叓直接エーテルで抽出して作つた抗原む， 谏結乾燥材料をべンゼンで抽出した抗原も共に所謂可 溶性抗原の性質安もち，10,000 r.p.m.20分遠心した沈 渣には染色上リケッチアも証明されず何の抗原性も 見られなかつた。エーテル抽出は，低温で最短5分に 止めて抗原孝作製したことあるるが依然として沈澘に は抗原性か語正明されなかつた。 
Table 5. Immunizing Potencies of Vaccines Prepared from Crude Yolk Sac Infected with AX Strain.

\begin{tabular}{|c|c|c|c|c|c|c|c|c|c|c|}
\hline \multirow{2}{*}{$\begin{array}{c}\text { Challenge } \\
\text { Stain }\end{array}$} & \multirow{2}{*}{ Mice } & \multicolumn{7}{|c|}{ Dilution of Inoculum } & \multirow{2}{*}{ LD 50} & \multirow{2}{*}{$\begin{array}{c}\text { Immunity } \\
\text { Index }\end{array}$} \\
\hline & & $10^{-2}$ & $10^{-3}$ & $10^{-4}$ & $10^{-5}$ & $10 \sim 6$ & $10^{-7}$ & $10^{-8}$ & & \\
\hline \multirow{2}{*}{$\mathrm{AX}$} & Control & $6 / 6$ & $6 / 6$ & $6 / 6$ & $6 / 6$ & $4 / 6$ & $2 / 6$ & $0 / 6$ & $10^{-6.5}$ & \multirow{2}{*}{1.2} \\
\hline & Vaccinated & $6 / 6$ & $6 / 6$ & $6 / 6$ & $3 / 6$ & $2 / 6$ & $0 / 6$ & $0 / 6$ & $10^{-5.3}$ & \\
\hline \multirow{2}{*}{$\mathrm{G}$} & Control & $6 / 6$ & $6 / 6$ & $6 / 6$ & $6 / 6$ & $6 / 6$ & $4 / 6$ & $1 / 6$ & $10^{-7.4}$ & \multirow{2}{*}{2.2} \\
\hline & Vaccinated & $6 / 6$ & $5 / 6$ & $3 / 6$ & $4 / 6$ & $2 / 6$ & $1 / 6$ & $0 / 6$ & $10^{-5.2}$ & \\
\hline
\end{tabular}

リケッチア感染䁒黄囊乳刜のハッカネズミに対する 免度原性：少つて著者は羽里教授と共に畉黄囊孚剂上

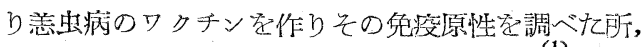
予期に反しそれは殆んど效果学示さな引つた。当時使 用されたワクチンは町黄囊学 2 パーセントに稀釈した ものであり、リケッチアの含有量が少かつたと思はれ る点も㐫り，こ入にそれらの点加再検討された。 上述 の抗原の作製と同様りケッチアのよく増殖した畉黄露 の10パーセント乳剂空作り直ちに10,000 r.p.m. 20分聞 遠心してその上清安すて, 沈渣究原量と等量の生理的 食塩水に再浮游して更に 2,000 r.p.m. 10分遠心した上 清にマーサィオレィト定一万倍の割合に加えて1週間

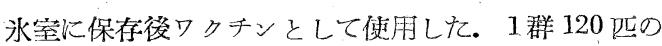
ハッカネズメを各 $0.3 \mathrm{~m} 1$ づ〉 5 日扣きに 3 回免疫し最 後の免疾注射より 2 週聞目に AX 株及びG株䍜患ハッ カネズミの肝，脾乳剂の各稀釈空 $0.3 \mathrm{ml} つ ゙>1$ 群 6 乃 至 7 元の免疫動物の腹腔内に注射した。第 5 表に明分 な様に甽黄囊より作られてワクチンも腹挖内注射によ りハッカネズミ至免疼すれば或程度の免疫效果究有す るものである。

前回の報告に於ては甽黄意ワクチンはハッカネズミ の皮下に注射された. Lewthwaite等も感染甽黄罍よ りエーテル抽出，或は無妈置の委〉ワクチンを作り， ハッカネズミ怘皮下注射により免疾しているが，いづ れも無效であること学報告している。そこで急度注射 の方法及び卵黄营ワクチンの免度原性に及䄈すェー

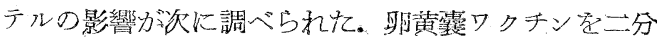
し，その一部は無㚭置の来入残し他の一部安低温で等 量のエーテルを加えて30分間观置し水層部を分離して ワクチンとした。免疫の方法は前回と同样であり，た ら゙一群のネボミには腹腕内免疫群と等量のワクチンを 皮下に接種した。結果は篔6表に示されている。この

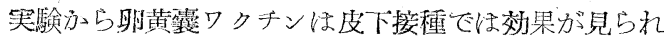

Table 6. Influence of Ether-extraction on the Immunogenicity of Crude Yolk Sac Vaccine

\begin{tabular}{c|r|r|r|r|r}
\hline $\begin{array}{c}\text { Dilution of } \\
\text { Cha1lenge } \\
\text { Inoculum }\end{array}$ & \multicolumn{2}{|c|}{$\begin{array}{c}\text { Crude Yolk } \\
\text { Sac Vaccine }\end{array}$} & \multicolumn{2}{|c|}{$\begin{array}{l}\text { E.ther-extract- } \\
\text { ed Yolk Sac } \\
\text { Vaccine }\end{array}$} & \multirow{2}{*}{ Contro1 } \\
\cline { 2 - 5 } & I.P.* & S.C.** & T. P. & S. C. & \\
\hline $10^{-2}$ & $4 / 6$ & $6 / 6$ & $5 / 6$ & $6 / 6$ & $6 / 6$ \\
$10^{-3}$ & $4 / 6$ & $6 / 6$ & $5 / 5$ & $5 / 5$ & $6 / 6$ \\
$10^{-4}$ & $3 / 6$ & $3 / 6$ & $4 / 6$ & $5 / 6$ & $5 / 6$ \\
$10^{-5}$ & $2 / 6$ & $4 / 6$ & $3 / 6$ & $3 / 6$ & $3 / 6$ \\
$10^{-6}$ & $0 / 6$ & $1 / 6$ & $1 / 6$ & $2 / 6$ & $1 / 6$ \\
$10^{-7}$ & $0 / 4$ & $0 / 5$ & $0 / 6$ & $0 / 6$ & $0 / 5$ \\
\hline LD $D_{50}$ & $10^{-3.7}$ & $10^{-5.0}$ & $10^{-4.7}$ & $10^{-5.2}$ & $10^{-5.0}$ \\
\hline Immunity & 1.3 & 0 & 0.3 & -0.2 & \\
index & & &
\end{tabular}

* Immunized through intraperitoneal route

* Immunized through subcutaneous route.

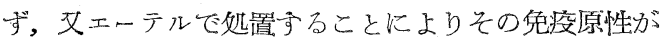
失はれること定知るのである。

恙虫病ワクチンの力洒に及ぼす検定株の影響：第 2 表及び第 3 表に示されで補体結合反応の結果よりも新 潟の恙出病流行地に於て同一年内に分離された株の間 の抗原性の美のあるとが想像される。他方ワクチン の免疫効果はそれを検定する梅の抗原性により大きく 影響されることは既に Rights 等により報告されてい る・リケッチア梠の間の抗原性の差を知るためには交

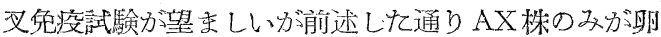
黄囊でよく増殖するためワクチンはAX株夌用いて作 り，その效力検定に他の数株学伎用して。. ワクチンは Smadel 等の方法により ダイコクネズミの臓器から作 られた。 AX 株感染町黄囊学生理的食塩承で10倍乳剂 とL, 3,000 r.p.m. 15 分遠心上清学取り試験管に分注 して氷水中で冷却しその $1 \mathrm{ml}$ 学体量80 100gr.のダイ コクネボミ15暨の尾静脈に接種した。亦ズミは接種後 
Table 7. Resistance of Mice Immunized with AX Vaccine of Rat Tissue Type to Challenge Infection with Strains of Tsutsugamushi Disease Rickettsia.

\begin{tabular}{|c|c|c|c|c|c|c|c|c|c|c|c|}
\hline \multirow{2}{*}{$\begin{array}{l}\text { Challenge } \\
\text { Rickettsial } \\
\text { Strain }\end{array}$} & \multirow{2}{*}{ Mice } & \multicolumn{8}{|c|}{ Dilution of Challenge Inoculum } & \multirow{2}{*}{$\mathrm{LD}_{50}$} & \multirow{2}{*}{$\begin{array}{c}\text { Immunity } \\
\text { Index }\end{array}$} \\
\hline & & $10^{-1}$ & $10^{-2}$ & $10^{-3}$ & $10^{-4}$ & $10^{-5}$ & $10^{-6}$ & $10^{-7}$ & $10^{-8}$ & & \\
\hline \multirow{2}{*}{$\mathrm{AX}$} & Control & $6 / 6$ & $6 / 6$ & $6 / 6$ & $6 / 6$ & $0 / 6$ & $5 / 6$ & $0 / 6$ & $0 / 6$ & $10^{-6.4}$ & \multirow{2}{*}{1.3} \\
\hline & Vaccinated & $5 / 6$ & $6 / 6$ & $6 / 6$ & $4 / 6$ & $4 / 6$ & $2 / 6$ & $0 / 6$ & $0 / 6$ & $10^{-5.1}$ & \\
\hline \multirow{2}{*}{ S. 4} & Control & $6 / 6$ & $6 / 6$ & $6 / 6$ & $6 / 6$ & $4 / 6$ & $2 / 6$ & $0 / 6$ & & $10^{-5.5}$ & \multirow{2}{*}{2.8} \\
\hline & Vaccinated & $6 / 6$ & $2 / 6$ & $2 / 6$ & $2 / 6$ & $1 / 6$ & $1 / 6$ & $0 / 6$ & & $10^{-2.7}$ & \\
\hline \multirow{2}{*}{ S. 6} & Control & $6 / 6$ & $6 / 6$ & $6 / 6$ & $6 / 6$ & $4 / 6$ & $2 / 6$ & $1 / 6$ & & $10^{-5.6}$ & \multirow{2}{*}{3.3} \\
\hline & Vaccinated & $4 / 6$ & $3 / 6$ & $2 / 6$ & $1 / 6$ & $1 / 6$ & $0 / 6$ & $0 / 6$ & & $10-2.3$ & \\
\hline \multirow{2}{*}{ S. 11} & Control & $6 / 6$ & $6 / 6$ & $6 / 6$ & $6 / 6$ & $6 / 6$ & $4 / 6$ & $3 / 6$ & $0 / 6$ & $10^{-6.7}$ & \multirow{2}{*}{2.1} \\
\hline & Vaccinated & $6 / 6$ & $6 / 6$ & $4 / 6$ & $4 / 6$ & $2 / 6$ & $1 / 6$ & $2 / 6$ & $0 / 6$ & $10^{-4.6}$ & \\
\hline \multicolumn{2}{|c|}{$\begin{array}{l}\text { Infective titer of vaccine } \\
\text { before adding merthiolate }\end{array}$} & $6 / 6$ & $6 / 6$ & $6 / 6$ & $6 / 6$ & $6 / 6$ & $6 / 6$ & $6 / 6$ & $2 / 6$ & $10-7.7<$ & \\
\hline
\end{tabular}

4. 日目には舟吸頻数, 結膜炎学起し食思定失 万以至る。

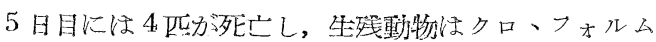
で殺しその充血肥大した睡及び肺等据出して科量しガ

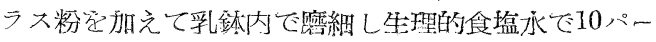
セント乳鄅とする。それ学3,000 r.p.m. 10分間遠心し て上清究取り形の如くその感染洒学測定後 1 万㥉の割 合にマーサィオレイト定加えて氷窒に保存し 1 週間徣 にワクチンとして使用する。

一群 250 匹のハツカネズミ文前回と同様の方法でダ イコクネズミ臓器ワクヂンにより免疫した。最後の注 射より16日前後に S.4, S.6, S. 11及び AXの各株に感 染し頻死のハッカネズミ各3 低の肝の10倍乳剂学作 り，脱脂乳にて階段的に 10 倍稀釈し各稀瀵の $0.3 \mathrm{ml}$

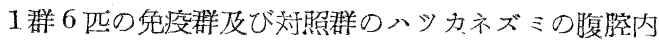
に接福した。動物は 3 週間観察してその.LD50学算出 した. 第7表に示されている様にAX株から作られた ワクチンの兔庱效果は検定株によりうなり相違してい。 る・之等の結果は更に别の笑験によつても確められて。

\section{論議}

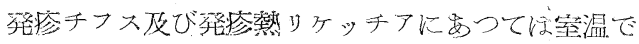
エーテル処置安行えば所謂可溶性抗原の部分が分離 し，之学遠心することにより各りヶッチアに特黑的な 抗原と可溶性抗原との分離が可娟で出ることは血清学 的方法に加えてShepard等により電子顕微鏡学用いて

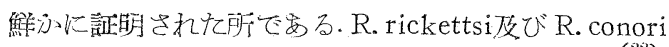
の間にも之と同様な関係が成立することも Plotz 等に
より証明されている。他方Q熱リケッチアに亦つては エーテルその他の方法定以てしても可浴性抗原は趾 されない。恙蛙りケッチアでは土ーテル, 病りゼン 等至室温或は低温で作用させても抗原は可溶性抗原の 性状学星 L 10,000 r.p.m. 20分遠心しても抗原性定もつ て粒子は全然証明されない。エーテル㚭理は低温で僅 う5 分の缶合にも既にリォッチアほすべて10,000 r.p. m. の遠心で泿降不能の微粒子K分散する事突は他の リケッチアと対比し恙虫病りケッチアの特徽字なする のである。とのリケッチアは感染動物の組織中です破 壞劣らけて可溶性抗原となることはハッカネズミの㿻 清友び胁膜院液中に証明した Smade1 等, 或は患者の 尿中に証明した ○'Connorの報告にも明かでるる。之 等の事笑は恙虫病りケッチアガ非常に破壊され易い无 のであることを更に物語つている.

前報に於ける患者等の突験, 或は Lewthwaite 等の 笑験によれば町黄囊乳都の免疫原性ほ証明されていな いが，本報告に述へられた様にリォッチアの含有量が 多ければネズミの感染組織乳悋と同様それは免疫原性

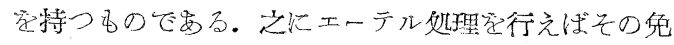
疫原性は失はれる。可溶性抗原の形で守 in vitroの抗

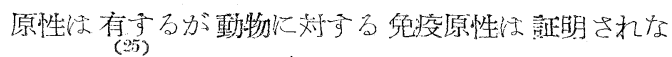

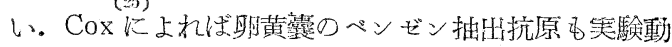
物に対しては免疾原性がないとのことである。郋黄囊 ウらワクチン学作るためにはエーテル等の有機溶媒の 使用学さ就ければならないでする。

日本の恙虫病りケッチアの株の間にも抗原性の差が 
存在することはPhilipによつて示唆された所である。 著者は且てフィリツピンのVolner 株空使用しアメリ カ軍医学校で作られた恙虫病ワクチンの日本の株に対

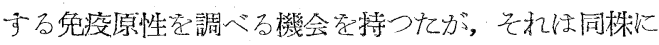
対しては 3.5 以上の免疾原性学特つにも拘らず日本の

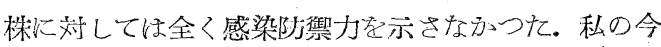
回の美験ではワクチンがAX一株のみから作られてい。 るため各株の間の抗原性の营定定量的に測定すること ほ出来なかつた。な少AX株のダイコクネズミ臓器ワ クチンが同株よりも異株の感染に対してより強い免疫 原性を元すと云う奇異な結果を得たが, Rights等も之 と同様の結果をMite-21 株で報告している。之等の結 果住AX或住Mite-21株等の強い組織侵入性によるも のと解釈したいがここの点については更に別報にりず 万.

\section{総括}

1. 新潟で分離された数株の喜虫病りケッチア邲黄䨗 に於ける堌殖性力此較されて。.多くの株は染色上り ケッチア空靖明不可能であつたがその内の一株のみ がリケッチアの増殖性強く、株により㥸黄囊に対す

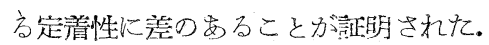

2. $\mathrm{AX}$ 株畉黄欜乳剩よりエーテル及びベンゼン拙出 法に上り補体結合反応抗原か作られたが，それらは いづれも可溶性抗原に属するものでする.

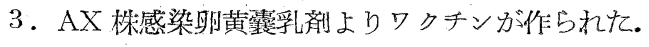
出発材料がリケッチアを多く含有すればそれは免度 原性をるつがェーテル观置により色度原性孝失う。

4. 補体結合反応及びワクチンによる感染防㓡試験に より，新潟の株の間には抗原性の美のあるととが示 唆された。

\section{文献}

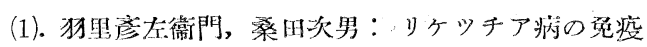
に関する実驗的研究(第2 2 報) Rickettsia orientalis

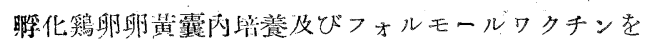
以て技疫試驗，日本細菌学楛誌，1，66-77，1944 (2). Bengtson, I.A. : Complement fixation in tsutsugamushi disease (scrub typhus).Pub. Health Rep., 61, 895-900, 1946 (3). Topping, N. H. \& Shepard, C. C. : A method for the preparation of tsutsugamushi (scrub typhus) antigen from infected yolk sacs. Pub. Health Rep., 61, 778-781,
1946 (4). Clancy, C. F. \& Cox, H. R. : The cu1tivation of Rickettsia orientalis fertile hens' eggs. J. Bact., 51, 629, 1946 (5). Smadel, J. E., Jackson, E. B. \& Bennett, B.L. : A toxic substance associated with the Gilliam strain of $\mathrm{R}$. orientalis. Proc. Soc. Exp Biol. \& Med., 62, 138 $-140,1946$ (6). Bengtson, I. A. : Apparent heterogeneity among strains of tsutsugamushi disease (scrub typhus). Pub. Health Rep., 60, 14831488, 1945. (7). Bengtson, I. A. : A serological study of 37 cases of tsutsugamushi disease (scrub typhus) occuring in Burma and the Philipine Island. Pub. Health Rep., 61, 887-894, 1946 (8) 勿里彥左衛門, 西村敏而, 桑田次男：リケッチア病

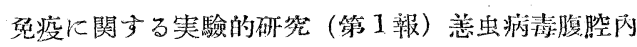
感廿日鼠乳郕ワクチンを以てせる能働性桑疫に就い て, 日本細菌学雜誌, 1, 61-65, 1944 (9). Smade1, J. E., Rights, F. L. \& Jackson, E. B. : Studies on scrub typhus, II. Preparation of formalinized vaccines from tissues of infected mice and rats. Proc. Soc. Exp. Biol. \& Med., 61, 308-313, 1946 (10). Fulton, F. \& Joyner, L. : Cultivation of Rickettsia tsutsugamushi in lungs of rodents. Preparation of a scrub typhus vaccine. Lancet, 7 29-733, 1945 (11). Plotz, H., Bennett, B. L. \& Reagan, R.L. : Preparation of an inactivated tissue culture scrub typhus vaccine. Proc. Soc. Exp Biol. \& Med., 61, 313-317, 1946 (12). Bailey, C., Diercks, F. H. \& Profitt, J.E.: Preparation of a serological antigen and a vaccine for experimental tsutsugamushi disease (scrub typhus). J. Immunol., 60, 431-441, 1948 (13) 桑四次男： 恙虫病に於ける蛋疫の分析, ウイールス，1, 101-10 6, 1951 (14). Smadel, J. E. : Serological procedures for the diagnosis of rickettsial diseases. Diagnostic Procedures for. Virus and Rickettsial Diseases. pp. 311-333, 1948 (15). Lewthwa1te, R., O'Connor, J. L. \& Williams, S.E. : The tsutsugamushi disease : attempted preparation of a prophylactic vaccine from fertile hens' eggs expertmentally infected with the virus. Med. J. Austra1., II, 37-43, 1946 (16). Wolff, D. M., Van der Scheer, J., Clancy, C. F. \& Cox, H. R. : Me- 
thod for the preparation of complement-fixing antigens in a stuedy of experimental tsutsugamushi disease(scrub typhus). J. Bact. 51, 247-255, 1946 (17). Espana, C. \& Hammon, W. Mc D. : An improved benzene eaxtrcted complement fixing antigen applied to the diagnosis of the arthropod-borne virus encephalitides. J.1mmuno1., 59, 31-44, 1948 (18). Smade1, J. E., Rights, F. L. \& Jackson, E.B.: Studies on scrub typhus I. Soluble antigen in tissues and body fluids of infected mice and rats. J. Exp. Med., 83, 133-14 6, 1946 (19). Rights, F. L., Smade1, J. E. \& Jackson, E. B.: Studies on scrub typhus (tsutsugamushi disease). III. Heterogeneity of R. tsutsugamushi as demonstrated by cross-vaccination studies. J. Exp. Med., 87, 339-351, 1948 (20). Wishart, F. C. \& Malcomson, N. E. : Studies of the serology of typhus fever, Canadian T. PubHea1th, 37, 367-381, 1946 (21). Shepard, C.C. \&
Wyckoff, R. W. G. : The nature of the soluble antigen from typhus riekettsiae. Pub. Health Rep., 61, 761-767, 1946 (22). Plotz, H., Reagan, R.L. \& Wertman, K : Differentiation between fièvre boutonneuse and Rocky Mountain spotted fever by means of complement fixation. Proc. Soc. Exp. \& Med., 55, 173-176, 1944 (23). Topping, N. H. \& Shepard, C. C. : The preparation of antigens from yolk sacs infected with rickettsiae. Pub. Health Rep., 61, 701-707, 1946 (24). O'Connor, J. L. : Excretion of specific antigen in the urine in Tsutsugamushi disease (Scrub typhsu). Brit. J. Exp. Path., 31, 51-64, 1950 (25) Cox, H. R.：私信 (26). Philip. C. B.: Observations on tsutsugamushi disease (miteborne or scrub typhus) in northwest Honshu Island, Japan, in the fa11 of 1945. 1. Epidemiological and ecological data., Am. J. Hyg., 46, 45-59, 1947

\title{
海めいの日本脑炎感染に関す万実験的砸究 第 3 報 病毒接種海めいの病理組織学 *
}

\author{
林博 ** \\ [受稿：4月23日, 1935]
}

主題の一連の研究に於て日本脳炎病毒（以下日㨫厂 ウ」と略記する）(中山株）接種に対して海めいの呈す 万症状，反応を詳細に検甞し，更に接種病毒の体内に 於ける消長と抗体産生との相闻多係空追求し, 得られ た結果の一部它既に報告した。

日盿「ウ」接種に於ける海めい諸臟器の病理組織学 に就ては極く部分的且つ簡単な報告は多るが詳細に報 告されたもの注見られない、私は海めいの笑験的日脳 感染に於棌子諸藏器の組織像学全般に亘つて検索し若 干の知見定得たので泫に報告する。

\section{実験材料と方法}

体重400～500g の海めい(以下モルと略す) 65飞定 撰び（性別なし）之等の内40匹脳左半球乃至左大㯊 等内に日畝「ウ」(中以株） $\left(\mathrm{LD}_{50}=7,5\right)$ の $10^{-1}$ 子 0.1

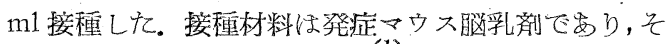
の調製法や接種法は第 1 報記載の通りである. 30 匹の 脳内接種群は接種後々の内の 15 匹就き逐日 $3 ， 6,10$, 15,20 , 日目に夫々 3 匹宛エーテル麻酔て殺し直らにそ

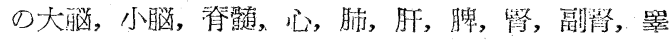
丸，四采，唾液腺，淋巴腺（䣆部，肺門部，腸間膜，

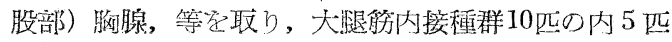
に就ては之等の諸藏器の他に更にその接種部位及び他 側肢の大腿腔起剔出し，直らにフォルマリン固定とア

* 本論交の要旨は昭和 27 年4月 8 日第25回日本細菌学全総会（福岡）に於て口演した。

** 精神医学研炎所 (乘京都板橋区茂克町3639番地) 